\title{
Peran Pondok Pesantren dalam Pembinaan Keberagamaan Remaja
}

\author{
Wahyu Nugroho \\ Ponpes al-Hasan, Salatiga \\ nugroho45@yahoo.co.id \\ DOI: 10.18326/mudarrisa.v8i1.89-116
}

\begin{abstract}
Abstrak
Penelitian ini berupaya menggali lebih dalam dalam tentang relasi masyarakat dengan pondok pesantren dan peran pondok pesantren dalam pembinaan keberagamaan remaja. Pertanyaan utama yang ingin dijawab melalui penelitian ini adalah bagaimana perilaku keberagamaan remaja, bagaimana peran pondok pesantren dalam meningkatkan perilaku keberagamaan, dan apa problematika pembinaan keberagamaan remaja. Metode yang penulis gunakan dalam penelitian ini adalah penelitian kualitatif. Penelitian ini dilakukan mulai bulan November 2013 di pondok pesantren al-Hasan. Responden dalam penelitian ini terdiri atas, pengasuh, pengurus dan santri serta remaja sekitar. Teknik pengumpulan data yang digunakan dalam penelitian ini adalah wawancara dan observasi. Setelah melakukan analisis, di peroleh hasil penelitian yang menunjukkan bahwa keberagamaan remaja yang beragam dan agak minim. Peran pondok yang dijalankan sebagai fasilitator, mobilisasi, sumber daya manusia, agent of development dan agen of excellence kurang berjalan maksimal. Pembinaan yang dilakukan kurang berjalan maksimal karena di pengaruhi berbagai faktor salah satunya kurang komunikasi antara remaja dengan pondok pesantren.
\end{abstract}

This study seeks to dig deep inside of people's relationships with the boarding school and the role of religious boarding school in coaching teenagers. The main question to be answered through this research is how the behavior of adolescent religious boarding school ?, what are the 
roles of boarding school in increasing the religious behavior? What are the problems of fostering teenagers religiosity? It is a qualitative research. This study was conducted from November 2013 in the al-Hasan boarding school. Respondents in this study consisted of caregivers, administrators and students as well as the teen around. Data collection techniques used in this research is interview and observation. The results show that religious teens are varied and somewhat lack. The role of the boarding school as a facilitator, mobilization, human resources, an agent of development and agents of excellence are not running optimally. Coaching is in less effect since it was influenced by many factors, one of which is less communication between adolescents with boarding school.

Kata kunci: pesantren, pembinaan, remaja, keberagamaan

\section{Pendahuluan}

Pesantren sejak awal tumbuh dan berkembang di berbagai daerah Indonesia, telah dikenal sebagai lembaga keislaman yang memiliki nilainilai strategis dalam pengembangan masyarakat Indonesia. Sejak kemunculannya ratusan tahun yang lalu, telah menjangkau berbagai lapisan masyarakat khususnya masyarakat muslim. Kehadiran pesantren telah diakui pula sebagai lembaga pendidikan yang turut serta mencerdaskan kehidupan bangsa.

Pondok pesantren memiliki berbagai peran penting dalam meningkatkan kualitas sumber daya manusia. Seperti yang umumnya diketahui, pesantren sebenarnya tidak hanya memberikan pengetahuan dan keterampilan teknis, tetapi yang jauh lebih penting adalah menanamkan nilai-nilai moral dan agama. Filosofi pendidikan pesantren didasarkan atas hubungan yang bermakna antara manusia dengan Allah SWT Hubungan tersebut memiliki makna jika bermuatan atau 
menghasilkan keindahan dan keagungan. Ibadah yang dijalani oleh semua guru dan santri di pondok pesantren diutamakan dalam hal mencari ilmu, mengelola pelajaran, mengembangkan diri, mengembangkan kegiatan bersama santri dan masyarakat (Nafi', dkk, 2007:9).

Kondisi tersebut juga sama halnya dengan pondok al-Hasan yang didirikan pada tahun 1960an oleh Bapak Isom. Beliau pada awalnya adalah seorang pengajar jamaah pengajian di Desa Bancaan, Salatiga. Hal tersebut dikarenakan beliau ikut berhijrah ke tempat istri mudanya yang berada di Dusun Banyu Putih, Kabupaten Semarang sehingga para jamaah yang dulunya belajar mengaji di Desa Bancaan juga mengikuti sang ustadz pindah dan meneruskan kegiatan di sana. Seiring dengan perkembangannya kini, pondok pesantren al-Hasan telah menjadi pondok pesantren ternama di daerahnya. Nama al-Hasan diambil dari sebuah nama masjid di dekat beliau tinggal dan dijadikan sebagai tempat mengajarkan pengajian. Hingga saat ini pengelolaan pondok tersebut telah memasuki generasi ketiga yang diasuh oleh Bapak KH. Ichsanudin, MZ.

Santri di pondok pesantren al-Hasan yang dulunya diprakarsai oleh para generasi tua, kini mulai didominasi oleh para remaja dan anakanak usia sekolah. Hal tersebut bukan menjadi suatu hambatan bagi pengasuh pondok al-Hasan untuk mengembangkan visi misinya. Namun justru meningkatkan aura positif di dalam kehidupan pondok. Ini merupakan salah satu bukti bahwa sebenarnya remaja memiliki peranan yang besar bagi perubahan zaman. 
Usia remaja merupakan fase perkembangan yang sangat dinamis. Pada masa ini merupakan peralihan yang ditempuh seseorang dari anakanak menuju dewasa, karena mereka mulai mencari jati dirinya. Remajaremaja seringkali menarik diri dari masyarakat, acuh tak acuh terhadap lingkungan sekitar, bahkan terkadang mereka menentang adat kebiasaan dan nilai-nilai yang dianut masyarakat sekitar. Hal ini dikarenakan mereka tidak mendapat tempat dan kedudukan yang jelas dalam masyarakat, pendapat dan keinginannya kurang didengar, karena dipandang kurang matang.

Sikap atau perlakuan masyarakat tersebut dapat mempertajam konflik yang sebenarnya telah ada pada diri remaja. Mereka lebih memilih bergabung dan bersenang-senang dengan teman sebayanya ketika menghadapi sebuah masalah dibandingkan dengan melakukan halhal yang dapat meningkatkan religiusitasnya. Sama halnya dengan remaja Dusun Banyu Putih Timur, Sidorejo Lor, Salatiga. di sana jarang sekali ditemui anak-anak usia remaja yang aktif dalam kegiatan-kegiatan keagamaan. Hanya beberapa saja dari mereka yang aktif itupun remaja usia sekitar 13-15 tahun atau mereka yang masih duduk di bangku Sekolah Menengah Pertama (SMP). Selebihnya, mereka memiliki berbagai kegiatan di luar dan jarang mengikuti kegiatan yang bersifat keberagamaan.

Glock dan Stark mengatakan bahwa sikap keberagamaan manusia dapat dilihat dari lima dimensi, yaitu: ideological, ritual, mistikal, intelektual, dan sosial. Sedangkan menurut Zakiah Daradjat (1996:35), agama seseorang ditentukan oleh pendidikan, pengalaman dan pelatihan- 
pelatihan yang dilalui semasa kecilnya dulu, seorang yang semasa kecilnya tidak pernah mendapatkan pendidikan agama maka pada saat dewasa nanti, ia kurang merasakan pentingnya akan agama dalam hidupnya, terutama pada anak usia remaja.

Seperti halnya dengan sebuah aliran empirisme yang di cetuskan oleh John Locke yang mana aliran ini memandang bahwa perkembang manusia ditentukan oleh pengalaman dari lingkungannya (Sriyanti, 2009:19). Misalkan seseorang yang berada pada lingkungan yang baik akan tumbuh menjadi pribadi yang baik pula. Pondok pesantren al-Hasan merupakan salah satu solusi bagi orang tua yang memiliki anak usia remaja dan ingin mengenalkan lebih jauh tentang agama kepada anakanaknya. Hubungan antara warga pesantren di satu pihak dan masyarakat di lain pihak meliputi berbagai aspek kehidupan, salah satunya yang bersifat pendidikan. Pihak warga pesantren terutama para kyai dan mubalig berperan sebagai pemberi informasi (komunikator), baik yang bersifat agama (melalui pesantren), maupun ilmu pengetahuan umum melalui lembaga-lembaga pendidikan formal yang ada di lingkungan pesantren. Sedangkan warga masyarakat khususnya remaja usia sekolah berperan sebagai penerima informasi (Galba, 1995:65-66).

Bagi sebagian remaja di Dusun Banyu Putih Timur, Desa Sidorejo Lor, Kota Salatiga, hal tesebut tidak berlaku. Meskipun tinggal di area pondok pesantren yang masyarakatnya memiliki sikap keberagamaan yang tinggi, Sebagian remaja di daerah tersebut kurang berminat dengan kegiatan keagamaan yang dilakukan oleh masyarakat sekitar maupun agenda pondok pesantren. Mereka memilih kegiatan yang 
cenderung berimplikasi negatif, misalnya menonton konser musik dibanding ikut kegiatan pengajian rutin hari minggu atau touring dengan klub motor yang diikutinya dan sibuk dengan hobinya daripada harus mengikuti jama'ah sholat di masjid. Hal tersebut mecerminkan merosotnya nilai-nilai kehidupan rohani dan degradasinya moral remaja.

Berdasarkan latar belakang masalah di atas maka ditemukan beberapa masalah, yaitu: 1) bagaimana perilaku keberagamaan remaja sekitar ponpes Al-Hasan, Dusun Banyu Putih Timur, Desa Sidorejo Lor, Kecamatan Sidorejo, Kota Salatiga; 2) bagaimana peran pondok pesantren al-Hasan dalam meningkatkan perilaku keberagamaan remaja Dusun Banyu Putih Timur, Desa Sidorejo Lor, Kecamatan Sidorejo, Kota Salatiga; 3) apa problematika pembinaan keberagamaan remaja di lingkungan pondok pesantren al-Hasan, Dusun Banyu Putih Timur, Desa Sidorejo Lor, Kecamatan Sidorejo, Kota Salatiga.

\section{Metode Penelitian}

Penelitian kualitatif adalah penelitian yang berusaha menemukan makna dari sebuah situasi atau kondisi. Metode penelitian ini berlandaskan pada filsafat postpositivisme yang memandang realitas sosial sebagai suatu yang utuh, komplek, dinamis dan penuh makna serta bersifat interaktif dan hasil penelitiannya lebih menekankan makna daripada generalisasi (Sugiyono, 2011:8). Dalam penelitian ini peneliti mencoba mencari tahu bagaimana sikap keberagamaan remaja pada lingkungan pondok pesantren. 
Penelitian ini menggunakan pendekatan lapangan (field research), dimaksudkan untuk mengetahui data responden secara langsung di lapangan, yakni suatu penelitian tentang studi yang mendalam mengenai suatu unit sosial sedemikian rupa sehingga menghasilkan gambaran yang terorganisir dengan baik mengenai unit sosial tersebut. Adapun metode penelitian yang digunakan adalah kualitatif..

Penelitian ini di lakukan di pondok pesantren al-Hasan, Dusun Banyu Putih Timur, Desa Sidorejo Lor, Kecamatan Sidorejo, Kota Salatiga. Sedangkan yang menjadi objek penelitian ini adalah pondok pesantren Al-Hasan. Subyek penelitian adalah orang dari lokasi penelitian yang dianggap paling mengetahui masalah penelitian guna memperoleh data-data penelitian. Informan adalah orang dari lokasi penelitian yang paling mengetahui permasalahan dan bersedia dijadikan sumber informasi, bersedia bekerja sama, mau diajak diskusi membahas hasil penelitian (Kasiram, 2010:283). Dalam penelitian ini yang menjadi subyek penelitian adalah pondok pesantren al-Hasan, Dusun Banyu Putih Timur, Desa Sidorejo Lor, Kecamatan Sidorejo, Kota Salatiga.

Fungsi dari subyek penelitian dan informan adalah membantu peneliti dalam waktu yang relatif singkat dapat memperoleh data yang banyak dan yang dibutuhkan selama penelitian berlangsung. Cara yang digunakan untuk mendapatkan informasi dari informan yang dapat dipertanggung jawabkan, dapat melalui wawancara. Untuk mendapatkan informasi yang dibutuhkan maka peneliti berpedoman pada informasi yang diberikan oleh pengurus pondok pesantren al-Hasan, para santri, dan remaja sebagai informan. 
Prosedur pengumpulan data yang digunakan oleh peneliti dalam mencari data dan informasi penelitian adalah dengan menggunakan metode wawancara, observasi, dan dokumentasi. Wawancara merupakan pertemuan dua orang untuk bertukar informasi dan ide melalui Tanya jawab, sehingga dapat dikonstruksikan makna dalam suatu topik tertentu (Sugiyono, 2011:231). Dalam hal ini penulis berpedoman pada informasi yang diberikan oleh pengasuh pondok pesantren, pengurus dan remaja Dusun Banyu Putih, Desa Sidorejo Lor.

Secara umum, observasi berarti pengamatan, penglihatan. Sedangkan secara khusus, dalam dunia penelitian, observasi adalah mendengar dalam rangka memahami, mencari jawab, mencari bukti terhadap fenomena social keagamaan (perilaku, kejadian-kejadian, keadaan, benda, dan symbol-simbol tertentu) selama beberapa waktu tanpa mempengaruhi fenomena yang di observasi, dengan mencatat, merekam, mempotret fenomena tersebut guna penemuan data analisis (Suprayogo dan Tabroni, 2001:167). Metode observasi dalam penelitian ini dimanfaatkan untuk mengamati kondisi remaja Dusun Banyu Putih Timur yang diharapkan dapat membantu untuk melengkapi data yang diperlukan dengan cara mengamati aktivitas kehidupan sehari-hari remaja tersebut.

Dokumen merupakan metode penelitian yang berbentuk tulisan, gambar, atau karya-karya monumental dari seseorang (Sugiyono, 2011:240). Peneliti menggunakan metode ini untuk mendapat data tentang kondisi dan keadaan Dusun Banyu Putih Timur, agamanya, dan sarana prasarana yang dimiliki dalam kegiatan keagamaan. 
Tahap analisis data dalam penelitian ini secara umum dimulai sejak pengumpulan data, reduksi data, penyajian data, dan penarikan kesimpulan atau verifikasi. Reduksi data merupakan proses pemilihan, pemusatan perhatian pada penyederhanaan, pengabstrakan, transformasi data kasar yang muncul dari catatan-catatan lapangan (Suprayogo, 2001:192-193). Pada proses ini peneliti dapat melakukan penggolongan, dan membuang yang tidak diperlukan. Setelah datanya terpilih maka dilakukan penyajian data yang didapat melalui informan dan data yang diperoleh dilapangan selama penelitian berlangsung. Penyajian data adalah menyajikan sekumpulan informasi yang tersusun yang memberi kemungkinan adanya penarikan kesimpulan dan pengambilan tindakan. Sehingga setelah penyajian data dapat ditarik kesimpulan sebagai hasil akhir penelitian.

Dalam melakukan pengecekan keabsahan data didasarkan pada beberapa kriteria. Kriteria tersebut terdiri dari credibility (derajat kepercayaan), transferability (validitas eksternal), dependability (reliabilitas) dan confirmability (obyektivitas). Masing-masing teknik tersebut menggunakan cara pemeriksaan sendiri-sendiri. Untuk kriteria derajat kepercayaan dalam memeriksa data maka peneliti memperpanjang keikutsertaannya, ketekunan dalam mengamati segala sesuatu objek di lapangan, triangulasi (teknik pengumpulan data yang bersifat menggabungkan dari berbagai teknik pengumpulan data dan sumber data yang telah ada), diskusi dengan teman sejawat, analisis kasus negatif dan member-check atau pengecekan data yang diperoleh peneliti kepada pemberi data (Sugiyono, 2011:270). 
Tahap-tahap yang dimaksudkan dalam penelitian kualitatif di bagi ke dalam tiga tahap, yaitu: tahap pra-lapangan, tahap pekerjaan lapangan, dan tahap analisis data (Moleong, 2009:127-148). Dengan demikian dapat dikatakan bahwa tahapan dalam penelitian ini adalah bentuk urutan atau berjenjang yakni dimulai dari tahap pra-penelitian, tahap pekerjaan lapangan, dan tahap pasca penelitian. Namun walau demikian, sifat dari kegiatan yang dilakukan pada masing-masing tahap tersebut tidaklah bersifat ketat, melainkan sesuai dengan situasi dan kondisi yang ada.

\section{Pondok Pesantren al-Hasan}

Pesantren berasal dari kata santri, yang berarti tempat tinggal para santri, Profesor Jhons berpendapat bahwa istilah santri berasal dari bahasa Tamil yang berarti guru mengaji, sedangkan C.C Berg berpendapat bahwa istilah tersebut berasal dari istilah shastri yang dalam bahasa India berarti orang yang tau buku-buku suci agama Hindu, atau seorang sarjana ahli kitab suci agama Hindu (Dhofier,1983:18).

Sedangkan pondok pesantren menurut Nurcholis Majid (1997:5) adalah tempat berkumpulnya para santri atau asrama tempat mengkaji ilmu agama Islam, di mana santri mempunyai image sebagai seorang yang mengerti lebih jauh mengenai perihal agama di banding masyarakat umum. Pesantren adalah lembaga pendidikan keagamaaan yang mempunyai ciri khasnya sendiri dibanding dengan lembaga pendidikan lainnya. Sebagai lembaga pendidikan yang sudah lama berkembang di Indonesia, pesantren berhasil membina dan mengembangkan kehidupan beragama masyarakat. 
Pondok pesantren merupakan sarana untuk menyiapkan para santri sebagai mutafaqqih fi al-din (mengkaji ilmu agama) yang mampu mencetak kader-kader ulama' dan pendakwah menyebarkan agama Islam, serta pembentukan akhlak. Selain itu, pondok pesantren juga dimanfaatkan masyarakat sebagai sarana mengembangkan kepercayaaan Islam, dan khususnya untuk mengembangkan kemampuan menafsirkan inti ajaran Islam. Sebuah pondok pesantren biasanya mempunyai elemenelemen yang mendukung eksistensinya. Elemen-elemen pondok pesantren setidaknya terdiri atas pondok atau asrama untuk santri, masjid, pengajaran kitab-kitab Islam klasik, santri, dan kyai (Dhofier,1983:44-55).

Masyarakat dan pemerintah mengharapkan pondok pesantren memiliki peranan yang besar terhadap pendidikan Islam di Indonesia, di antaranya adalah sebagai lembaga pendidikan dan keagamaan, tetapi juga sebagai lembaga pemberdayaan umat. Peran lainnya yaitu dapat memobilisasi masyarakat dalam perkembangan mereka, artinya lembaga ini dibangun atas dasar kepercayaan masyarakat bahwa pondok pesantren merupakan tempat yang tepat untuk menempa akhlak dan budi pekerti yang baik. Dalam sistem pendidikan yang dikembangkan oleh pondok pesantren sebagai upaya mengoptimalkan potensi yang dimiliki, pondok pesantren memberikan pelatihan khusus atau tugas magang dibeberapa tempat yang sesuai dengan pengembangan yang akan dilakukan di pondok pesantren.

Menurut Nurcholish Madjid (1997:104-105), pesantren dalam melihat dirinya, sebagai lembaga pendidikan apabila termasuk dalam 
empat kelompok. Pertama yang merupakan bagian terbesar, yaitu kelompok pesantren yang tidak menyadari dirinya, apakah bernilai baik atau kurang baik, mereka menganggap bahwa apa yang terjadi adalah terjadi begitu saja tanpa ada persoalan serius yang perlu dipikirkan. Kedua yaitu fanatik karena dengan kefanatikan tersebut sering membuat penilaian yang kurang obyektif. Ketiga adalah kelompok yang dihinggapi rasa rendah diri, sehingga mereka merasa menganggap identitas pesantrennya tidak perlu lagi dipertahankan. Keempat yaitu pesantren-pesantren yang sepenuhnya menyadari bahwa dirinya baik dari segi-segi positif maupun negative. Pondok tersebut dapat melihat dengan jernih mana yang harus diteruskan dan mana yang harus ditinggalkan.

Keberagamaan dan juga perilaku beragama tidak hanya menjadi bagian dari sistem kesadaran, tetapi juga menjadi bagian integral di dalam sistem sosial. Cakupan lingkup keberagamaan dalam Islam yang demikian utuh, telah mencakup seluruh segi kehidupan manusia, dan disebabkan olehpengaruh lingkungan yang sangat beragam. Perilaku keberagamaan seseorang tersebut memerlukan akurasi sosok dimensi yang konkret (Kadir, 2003:278).

Perilaku keberagamaan seseorang dapat pula dinilai dari berbagai aspek, diantaranya yaitu aspek ibadah atau ritual keberagamaannya. Ibadah dalam Islam sangat bermacam-macam bentuknya, maka dari itu islam membagi jenis-jenis pelaksanaan ibadah, seperti ibadah harian yang meliputi sholat lima waktu yang dalam Qs. al-Ankabut: 45 dinyatakan mempunyai fungsi dapat mencegah perbuatan mungkar (Abu Yasid, 2004: 45). 


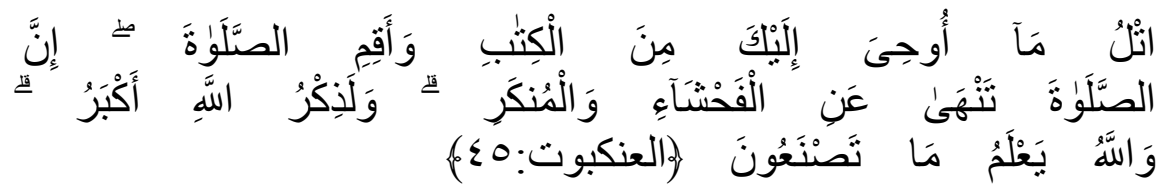

Sesungguhnya shalat itu mencegah dari (perbuatan- perbuatan) keji dan mungkar.

Adapun ibadah yang dilakukan mingguan yaitu sholat jumat seperti yang terkandung dalam Qs. al-Jumu'ah: 9.

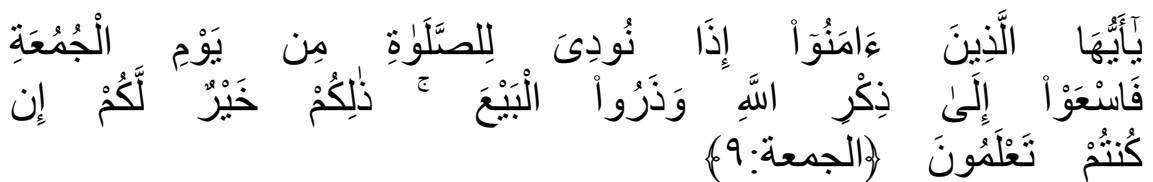

Hai orang-orang beriman, apabila diseru untuk menunaikan shalat Jum'at, Maka bersegeralah kamu kepada mengingat Allah dan tinggalkanlah jual beli. yang demikian itu lebih baik bagimu jika kamu mengetahui.

Ada pula ibadah tahunan seperti puasa ramadhan yang sangat efektif untuk meningkatkan keimanan dan ketaqwaan, sebagaimana dalam Qs. al-Baqarah: 183.

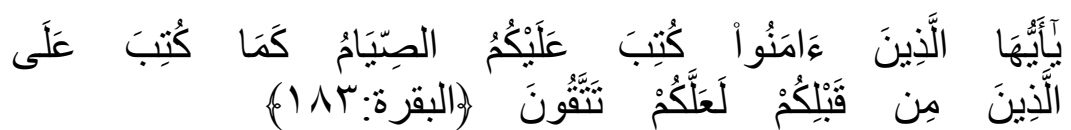

Hai orang-orang yang beriman, diwajibkan atas kamu berpuasa sebagaimana diwajibkan atas orang-orang sebelum kamu agar kamu bertakwa.

Perilaku keberagamaan akan melahirkan berbagai kreasi budaya dengan nilai kepercayaan yang termuat di dalamnya. Sebagai unsur yang berpengaruh bagi manusia, agama dapat memberikan layanan psikologi yang dibutuhkannya. Sementara manusia disisi lain juga memberikan kontribusi yang signifikan dalam membentuk tatanan dalam masyarakat. 
Pembinaan moral terjadi melalui pengalaman-pengalaman dan kebiasaan, yang ditanamkan sejak kecil oleh orang tua yang dimulai dengan pembiasaan hidup sesuai dengan nilai-nilai moral, yang ditirunya dari orang tua dan mendapat latihan untuk itu. Dalam pembinaan moral agama mempunyai peranan yang penting, karena nilai-nilai moral datang dari agama tetapi tidak berubah-ubah oleh waktu dan tempat. Dengan itu dapat ditegaskan bahwa Tuhan bagi remaja adalah keharusan moral. Tuhan lebih menonjol sebagai penolong moral daripada sandaran emosi.

Dalam menjalankan aktivitas-aktivitas agama, biasanya remaja sangat dipengaruhi oeh teman-temannya. Remaja yang sering menarik diri dari masyarakat dan acuh tak acuh kepada agama biasanya disebabkan karena perlakuan dan sikap masyarakat yang kurang memberikan kedudukan yang jelas seringkali mempertajam konflik yang ada pada diri remaja. Sehingga timbul kelompok-kelompok yang sikap dan tindakannya menentang nilai-nilai yang dianut masyarakat dan tak jarang yang menjadi sasaran adalah agama dan lembaga keagamaan. Jika lembaga keagamaan dapat memberi penghargaan dan menolong menyelesaikan masalah yang dihadapi remaja, maka remaja akan ikut aktif dan bekerja giat di bidang agama.

Keberadaan (eksistensi) pesantren beserta perangkatnya sebagai lembaga pendidikan dan dakwah serta lembaga kemasyarakatan yang telah memberikan warna di daerah-daerah serta tumbuh dan berkembang bersama mayarakatnya sejak berabad-abad. Oleh karena itu tidak hanya secara kultural lembaga ini bisa diterima, bahkan telah ikut serta memberikan corak nilai kehidupan masyarakat yang senantiasa tumbuh 
dan berkembang. Latar belakang pesantren yang paling patut diperhatikan adalah peranannya sebagai alat transformasi kultural yang menyeluruh dalam masyarakat (Dhofier, 2000:16).

Perkembangan teknologi dan ilmu pengetahuan yang sangat pesat mengalahkan segalanya. Kebanyakan anak-anak usia remaja sering banyak menghabiskan waktunya untuk berlama-lama dengan bersosial media yang tak jarang mereka sering mengabaikan praktik keberagamaannya seperti sholat berjamaah, dan mengikuti kegiatan yang dapat meningkatkan spiritualitasnya.

Pondok pesantren merupakan salah satu solusi dalam menghadapi masalah kontemporer yang dihadapi oleh masyarakat muslim masa kini. Masalah yang tengah berkembang saat ini, terlebih mengenai perilaku keberagamaan remaja sudah dapat dicarikan solusinya bersama-sama dengan cara dikembalikan pada syari'at hukum yang hakiki yaitu alQur'an dan Hadits.

Dalam meningkatkan perilaku keberagamaan remaja, pondok pesantren yang berkembang saat ini memiliki beberapa upaya dan langkah-langkah yang konkret selain menggunakan al-Qur'an dan Sunnah sebagai sumber dalam menghadapi berbagai permasalahan yang ada. Berbagai metode dan cara belajar juga telah dikembangkan dari masa ke masa. Bahkan pondok pesantren modern saat ini telah memanfaatkan berbagai macam teknologi yang sedang berkembang di masyarakat sebagai sarana dakwah dan menarik perhatian pemuda muslim untuk tetap mempelajari ilmu agama. Dengan demikian, tekhnologi tidak dijadikan kambing hitam merosotnya moral 
keberagamaan remaja manakala terdapat seorang yang mengarahkannya ke hal-hal yang positif. Selain memanfaatkan tekhnologi yang ada, pondok pesantren masa kini lebih banyak memberikan pelajaran yang bersifat empiris. Tujuannnya, setelah mereka keluar dari lingkungan pondok pesantren, dan terjun di lingkungan masyarakat mereka telah memiliki bekal yang cukup.

\section{Program Pembinaan Pondok Pesantren}

Berdasar hasil wawancara peneliti kepada informan tentang program yang dilakukan dalam meningkatkan keberagamaan remaja sekitar, dikemukakan bahwa tidak ada pembinaan yang khusus dari pondok pesantren untuk remaja. Seperti dipaparkan beberapa informan di antaranya sebagai berikut:

"Pembinaan remaja secara langsung itu tidak ada. Tetapi dalam praktiknya apabila ada remaja yang ikut mengaji atau di undang rapat ketakmiran atau kegiatan lain maka secara tidak langsung masyarakat dan pondok pesantren sudah ikut membina remaja", ujar KH (5 Desember 2013, 04.45 WIB).

Hal tersebut di perkuat juga dengan penuturan $\mathrm{T}$,

"Kalau pembinaan remaja tidak ada, tetapi setiap mengadakan acara apa saja pasti antara santri pondok dengan remaja saling membantu dalam melaksanakan kegiatan tersebut" (25 Desember 2013, 19.00 WIB).

Berdasar penuturan kedua informan tersebut dapat digambarkan bahwa tidak terdapat program pembinaan yang khusus diadakan bagi remaja sekitar pondok pesantren. Meskipun demikian, pembinaan secara tidak langsung tetap dilaksanakan dan diwujudkan dalam berbagai 
bentuk kegiatan di antaranya mengadakan akhirusanah menjelang akhir tahun ajaran, di mana kegiatan ini melibatkan masyarakat sekitar pondok pesantren terutama para remaja untuk mengelola maupun menjadi pengisi acaranya. Begitu pula dengan pondok pesantren al-Hasan yang juga mengadakan kegiatan tersebut. Itu merupakan salah satu tanda bahwa ada upaya kongkrit dari pondok pesantren dalam meningkatkan keberagamaan remajadi sekitarnya.

Kegiatan lain yang sudah biasa dilakukan yaitu peringatan hari besar Islam di Dusun Banyu Putih Timur yang diisi dengan pengajian misalnya pada peringatan Isra' Mi'raj, halal bi halal, Maulid Nabi Muhammad SAW dan sebagainya. Pondok pesantren al-Hasan juga menyelenggarakan kegiatan yang sama dengan bekerjasama dan melibatkan masyarakat sekitar khususnya remaja sebagai pelaksana acara. Dengan diadakannya peringatan hari besar Islam tersebut, diharapkan intensitas pertemuan antara santri pondok pesantren dengan remaja sekitar semakin bertambah. Sehingga tetap terjalin komunikasi yang baik antara kedua belah pihak. Melalui kegiatan-kegiatan yang beragam seperti contoh tersebut, secara tidak langsung pembinaan keberagamaan remaja di Dusun Banyu Putih Timur dapat berjalan dengan baik.

Bentuk kegiatan lain yang dapat melibatkan peran serta remaja di sekitar pondok pesantren al-Hasan adalah dengan didirikannya Taman Pendidikan al-Quran (TPQ). Taman Pendidikan al-Quran merupakan salah satu bentuk pembelajaran yang disediakan pondok pesantren alHasan bagi masyarakat sekitar. Mereka yang memiliki anak usia sekolah 
dapat menitipkan anaknya untuk belajar mengenai Islam di Taman Pendidikan al-Quran tersebut. Dari beberapa keterangan informan di atas dapat disimpulkan bahwa program pembinaan yang diadakan oleh pondok pesantren al-Hasan terhadap keberagamaan remaja kurang berjalan maksimal. Hal ini dikarenakan berbagai faktor baik dari internal maupun eksternal.

\section{Pembinaan Keberagamaan dalam Pesantren}

Berdasarkan pengamatan yang penulis lakukan di lapangan dan teori pada bagian sebelumnya, maka peran pondok pesantren al-Hasan adalah sebagai fasilitator. Keberadaan pondok pesantren al-Hasan dapat dijadikan sebagai salah satu sarana untuk menambah pengalaman keagamaan masyarakat sekitar. Dalam hal ini pondok pesantren AlHasan sudah berupaya memberikan fasilitas dan pelayanan bagi terpenuhinya kebutuhan keberagamaan masyarakat sekitar. Berbagai kegiatan yang diagendakan pondok pesantren tidak lain bertujuan untuk memberikan pembinaan kepada masyarakat. Pondok pesantren al-Hasan juga melakukan hal yang sama. Ada beberapa kegiatan yang diperuntukkan bagi masyarakat khususnya remaja sekitar pondok pesantren. Kegiatan tersebut umumnya dilakukan dalam rangka membina akhlak dan perilaku keberagamaan remaja. Dengan melibatkan masyarakat khususnya remaja di sekitar pondok pesantren dalam bidang pendidikan dan keagamaan, diharapkan mampu menambah pengalaman

keberagamaan masyarakat. Sehingga perjalanan keberagamaan masyarakat didasarkan pada ilmu yang telah dikajinya. 
Peranan pondok pesantren berikutnya yaitu sebagai agent of development. Keberadaan pondok pesantren al-Hasan diharapkan dapat dijadikan sebagai kontrol sosial keberagamaan masyarakat. Kebiasaan pondok pesantren yang melibatkan remaja sekitar dalam beberapa kegiatan peringatan hari besar agama, menciptakan suasana akrab bagi remaja dan santri sehingga sesekali waktu mereka akan saling memberikan informasi yang positif.

Pondok pesantren sebagai agent of excellence bukan hanya berperan sebagai tempat untuk transfer ilmu agama tetapi juga ilmu pengetahuan umum. Sehingga pondok pesantren Al-Hasan berupaya menambahkan berbagai model pendidikan. Pondok pesantren Al-Hasan mengembangkan metode belajar yang sering di sebut dengan kajian diniyah.

Kesadaran yang mulai tumbuh mengenai pesantren sering kali dengan memberikan penilaian bahwa system dalam pondok pesatren merupakan sesuatu yang bersifat asli. Hal ini dengan sendirinya bernilai positif dan harus dikembangkan. Penilaian tersebut menempatkan dunia pesantren pada pengakuan yang mempunyai peranan dalam pertumbuhan dan perkembangan pendidikan nasional. akan tetapi dalam sistem pendidikan nasional dinilai belum mampu menandingi organisasiorganisasi pendidikan lainnya.

\section{Problematika Pembinaan Keberagaman Remaja}

Dimensi praktik agama mencakup perilaku pemujaan pelaksanaan ritual formal keagamaan, ketaatan dan hal-hal yang dilakukan seseorang untuk 
menunjukkan komitmen terhadap agama yang dianutnya. Di sini ditemukan bahwa banyak remaja yang kurang memperhatikan ajaranajaran agama, khususnya bagi para santri yang sering kurang memperhatikan waktu sholat karena disibukkan dengan berbagai hal sehingga apabila waktu sholat sudah iqomah masih banyak para santri yang belum bersiap-siap ke masjid untuk melaksanakan sholat berjama'ah bahkan ada yang tidak ikut berjama'ah.

Sama halnya dengan santri pondok pesantren al-Hasan, keberagamaan remaja di sekitar pondok pesantren terutama dalam kegiatan berjama'ah kurang intensif. Mereka yang berjamaah di masjid dan aktif berjama'ah karena jarak rumah yang dekat dengan masjid dan masih memiliki ikatan darah dengan kyai, mereka beralasan jika tidak sholat berjama'ah di masjid mereka merasa malu. Meskipun hanya sekali dalam lima waktu, mereka tetap berjama'ah dan biasanya masjid akan dipenuhi jama'ah remaja ketika shalat maghrib. Remaja sekitar banyak yang tidak tertarik dengan kegiatan masjid karena dipengaruhi berbagai faktor. Orang tua menjadi faktor utama minimnya keberagamaan remaja sekitar.

Kehidupan ekonomi masyarakat yang sebagian besar menengah ke bawah juga menjadi pemicu minimnya keberagamaan remaja sekitar. Orang tua yang sibuk dengan pekerjaannya maka secara tidak langsung berimbas pada anak. Akibatnya sekarang banyak anak remaja yang lebih mementingkan kegiatan perekonomian guna memenuhi kebutuhan jasmaniahnya tanpa mengimbanginya dengan kebutuhan spiritualnya. 
Kondisi ekonomi masyarakat yang seperti itu, tidak dapat dijadikan sebagai alasan untuk saling menyalahkan. Kebutuhan ekonomi merupakan kebutuhan pokok masing-masing individu, sedangkan religiusitas seseorang merupakan hak tiap-tiap individu pula. Tokoh masyarakat setempat tidak dapat menuntut banyak tentang religiusitas remajanya, mereka berprinsip yang terpenting remaja masih bisa dikendalikan dengan kegiatan-kegiatan yang positif karena berdampingan dengan lingkungan pondok pesantren. Dari berbagai ritual keberagamaan yang di alami remaja masih telihat adanya perilaku remaja yang kurang begitu taat dalam mengamalkan ajaran agama, seharusnya remaja mengamalkan ajaran agama dalam kehidupan sehari-hari agar pemahaman tentang keagamaannya sedikit-sedikit dapat bertambah, atau bahkan bisa melaksanakan sholat wajib tepat pada waktunya dan tidak menunda-nundanya lagi.

Pondok pesantren dapat dimanfaatkan untuk memperdalam ilmu keagamaan yang merupakan kebutuhan pokok spiritual masyarakat. Kemudian pengetahuan yang di dapat dari pondok harus bisa diamalkan dalam kehidupan sehari-hari agar bermanfaat sehingga orang tersebut dapat merasakan akan pentingnya ajaran agama.

Pengalaman keagamaan seseorang akan mampu mendorong dirinya untuk lebih mendekatkan diri kepada Tuhan yang diwujudkan dalam perilaku keberagamaannya. Hal tersebut terlihat pada beberapa remaja yang mengalami pengalaman spiritual sehingga menjadikan mereka lebih baik daripada sebelumnya, walaupun masih ada sebagian dari mereka yang acuh tak acuh terhadap pelaksanaan ritual agama. 
Problematika lain yang dihadapi yaitu hubungan antara remaja sekitar pondok pesantren dengan para santri sendiri. Bagi anak usia sekolah tingkat lanjut kadang memiliki rasa malu untuk belajar di pesantren karena merasa sudah besar dan terlambat untuk mengikuti pendidikan di pondok pesantren. Para remaja merasa minder untuk berkumpul dan bergabung dengan santri-santri di dalam pondok. Remaja di sekitar pondok pesantren sebagian besar adalah tamatan Sekolah Menengah Atas (SMA). Namun, adapula beberapa dari merekayang berpendidikan terakhir Sekolah Menengah Pertama (SMP). Sedangkan mayoritas santri di pondok pesantren al-Hasan adalah mahasiswa yang memiliki pengalaman luas dan pendidikannya lebih tinggi dibandingkan dengan remaja di sekitarnya. Sehingga seringkali remaja yang memiliki pendidikan lebih rendah merasa minder bahkan kurang nyaman ketika berkumpul dengan para santri di pondok pesantren tersebut.

Lingkungan yang kurang mendukung juga menjadi problematika. Pondok pesantren al-Hasan yang berlokasi di tengah-tengah lingkungan masyarakat, seharusnya dijadikan sebagai sarana untuk mengembangkan pengetahuan keagamaan. Namun hal tersebut kurang berlaku bagi sebagian besar remaja di lingkungan sekitar pondok pesantren. Kegiatan yang dilakukan di pondok pesantren sebenarnya ditujukan untuk pembinaan keberagamaan remaja, tetapi kebanyakan dari mereka menganggap pondok pesantren adalah tempat berkumpulnya kaum intelektual muslim.Oleh karena itu ketika remaja sekitar sering mengadakan kegiatan, dan di hadiri oleh ustadz pondok pesantren, mereka menjadi enggan untuk berkumpul bahkan mendekat, bukannya 
menyambut dengan pikiran dan tangan terbuka. Dengan adanya kondisi tersebut, mengakibatkan pembinaan keberagamaaan remaja di wilayah s ekitar pondok pesantren Al-Hasan, Dusun Banyu Putih Timur, Desa Sidorejo Lor, Kecamatan Sidorejo, Kota Salatiga tersebut semakin terhambat.

\section{Solusi dalam Pembinaan Remaja}

Sesuai dengan hasil pengamatan serta beberapa keterangan yang telah penulis peroleh di lapangan, maka sebagai solusi dari berbagai problematika pembinaan remaja tersebut yaitu dengan mengadakan pertemuan rutin setiap satu bulan sekali di minggu pertama ataupun pada minggu kedua. Pertemuan tersebut dilakukan untuk menjalin komunikasi baik secara intern remaja maupun antara remaja dengan pondok pesantren. Pembinaan kegiatan remaja dilakukan dengan cara mengadakan pertemuan rutin setiap bulan di minggu pertama ataupun pada minggu kedua. Pada prinsipnya pertemuan rutin hanya ditujukan untuk mengumpulkan remaja, sehinggaa pembinaan keberagamaan remaja sedikit demi sedikit dapat disampaikan dengan cara yang lebih ringan dan santai.

Solusi permasalahan yang lain adalah dengan mengikutsertakan remaja dalam berbagai kegiatan pondok pesantren. Pondok pesantren sebagai sarana meminimalisir masuknya pengaruh negatif terhadap perilaku keberagamaan remaja, sedapat mungkin mengikutsertakan remaja dalam berbagai kegiatan yang dilakukan oleh pondok pesantren. Hal tersebut dimaksudkan agar terjalin komunikasi yang harmonis antara 
remaja sekitar dengan santri pondok pesantren. Jika komunikasi antara keduanya dapat terjalin, maka pembinaan remaja dapat disampaikan melalui sosialisasi tersebut.

Pendekatan dengan orang tua merupakan salah satu upaya yang dilakukan pondok pesantren bersama dengan tokoh masyarakat dalam membina keberagamaan remaja. Keluarga merupakan faktor utama terbentuknya pribadi anak, terutama perkembangan keberagamaan pada anak. dengan alasan tersebut, pondok pesantren bersama dengan tokoh masyarakat memberikan sarana mengembangkan religiusitas anak, melalui program TPA. Orang tua yang memiliki anak usia sekolah disarankan untuk mengikutkan putra putrinya belajar di TPA, sehingga pembinaan keberagamaan remaja dapat ditanamkan sejak dini.

\section{Simpulan}

Berdasarkan hasil penelitian yang telah dilakukan, maka peneliti dapat mengambil simpulan bahwa keberagamaan remaja sekitar pondok pesantren dipengaruhi oleh kehidupan ekonomi masyarakat yang sebagian besar menengah ke bawah. Tokoh masyarakat setempat tidak dapat menuntut banyak tentang religiusitas remajanya, mereka berprinsip yang terpenting remaja masih bisa dikendalikan dengan kegiatankegiatan yang positif karena berdampingan dengan lingkungan pondok pesantren.

Peran pondok pesantren dalam meningkatkan perilaku keberagamaan remaja adalah sebagai fasilitator. Keberadaan pondok pesantren sedikit banyak memberikan peran bagi masyarakat khususnya 
para remaja sekitar pondok pesantren al-Hasan. Sebagian remaja telah memanfaatkan sarana yang disediakan sebagai tempat mengembangkan ilmu agama dan bertukar informasi kepada santri. Sehingga diharapkan program pembinaan berjalan secara maksimal. Kegiatan yang diadakan oleh pondok pesantren al-Hasan belum menyentuh semua lapisan masyarakat. Tetapi pondok pesantren telah berupaya memberikan pembinaan remaja melalui TPA. Kurangnya kesadaran dan komunikasi antara masyarakat (khususnya remaja) dengan pondok pesantren alHasan menjadikan terputusnya informasi keberagamaan yang akan disampaikan. Hal tersebut berimbas pada kualitas sumber daya manusia remaja sekitar pondok pesantren al-Hasan.

Pondok pesantren al-Hasan secara tidak langsung menjalankan perannya sebagai agent of development atau kontrol sosial. Meskipun kurang berjalan secara maksimal, namun pondok pesantren bersamasama masyarakat berupaya mengutamakan perkembangan akhlak remaja. Peran lainnya yaitu sebagai agent of excellence. Masyarakat sekitar pondok pesantren kurang tertarik dengan kegiatan yang dilakukan pondok pesantren al-Hasan. Mereka beralasan kegiatan yang diadakan kurang variatif. Meskipun demikian pondok pesantren al-Hasan berupaya memberikan sarana dan pelayanan bagi masyarakat yang ingin memperdalam ilmu agamanya.

Problematika keberagamaan yang terjadi di remaja sekitar pondok pesantren al-Hasan yaitu anak usia sekolah tingkat lanjut yang merasa malu untuk belajar di pesantren karena merasa sudah besar. Remaja merasa minder untuk berkumpul jadi satu dengan anak pondok. 
Problematika lainnya adalah kondisi lingkungan yang kurang mendukung.

Relasi pondok pesantren al-Hasan dengan masyarakat sekitar pondok pesantren terjalin secara individu maupun personal antara pondok pesantren al-Hasan dengan masyarakat tidak ada masalah yang berarti. Mereka sedapat mungkin menjalin komunikasi yang baik. Dalam hubungan kelembagaan, remaja sering disertakan dalam berbagai kegiatan yang diagendakan pondok pesantren. Hal ini menunjukkan adanya komunikasi yang baik terjalin antara lembaga pondok pesantren al-Hasan dengan masyarakat sekitar terutama kalangan remaja. Bukan hanya pondok pesantren al-Hasan saja yang berupaya membangun komunikasi dengan masyarakat, melainkan juga dari pihak masyarakat. Masyarakat di sekitar pondok pesantren mengakui keberadaan santri pondok dan menganggap mereka merupakan bagian dari masyarakat.

Pembinaan yang dilakukan pondok pesantren al-Hasan terhadap problematika keberagamaan remaja secara langsung yang dilakukan oleh pondok pesantren tidak ada, namun ada berbagai program yang diadakan pondok pesantren dan secara tidak langsung memberikan pembinaan terhadap keberagamaan remaja sekitar di antaranya: Akhirusannah, Peringatan hari besar Islam, Hari raya Qurban, dan Taman Pendidikan alQuran.

Dalam menghadapi problematika yang ada, pondok pesantren bersama masyarakat melakukan beberapa upaya di antaranya mengadakan pertemuan rutin setiap sebulan di minggu pertama atau 
kedua, mengikutsertakan remaja dalam berbagai kegiatan pondok pesantren, serta pendekatan dengan orang tua.

\section{Daftar Pustaka}

Darajat, Z. (1976). Pembinaan Remaja. Jakarta: PT. Bulan Bintang.

Darajat, Z. (1978). Problematika Remaja di Indonesia. Jakarta: PT. Bulan Bintang.

Darajat, Z. (1994). Peran Agama dalam Kesehatan Mental. Jakarta: CV. Haji Masagung.

Darajat, Z. (1996). Ilmu Jiwa Agama. Jakarta: PT. Bulan Bintang.

Depdiknas. (2007). Kamus Besar Bahasa Indonesia Edisi ketiga. Jakarta: Balai Pustaka.

Dhofier, Z. (1983). Tradisi Pesantren: Studi tentang Pandangan Hidup Kyai. Jakarta: LP3ES.

Fauzi, M. (2007). Agama dan Realitas Sosial Renungan dan Jalan Menuju Kebahagiaan. Jakarta: PT Raja Grafindo Persada.

Galba, S. (1995). Pesantren Sebagai Wadah Komunikasi. Jakarta: PT Rineka Cipta.

Ishomuddin. (2002). Pengantar Sosiologi Agama. Jakarta: Ghalia Indonesia.

Kadir, M. A. (2003). Ilmu Islam Terapan Menggagas Paradigma Amali dalam Agama Islam. Yogyakarta: Pustaka Pelajar.

Kasiram, M. (2010). Metodologi Penelitian Kualitatif-Kuantitatif. Yogyakarta: UIN-Maliki Press.

Madjid, N. (1997). Bilik-Bilik Pesantren Sebuah Potret Perjalanan. Jakarta: Paramadina.

Martin, R. C. (2002). Pendekatan Kajian Islam dalam Studi Agama. Surakarta: Muhammadiyah University Press.

Moleong, L. J. (2009). Metodologi Penelitian Kualitatif. Bandung: PT Remaja Rosda Karya.

Mu'tasim, R. (2010). Perlawanan Santri Pinggiran. Yogyakarta: PT. Bintang Pustaka Abadi. 
Mudarrisa, Jurnal Kajian Pendidikan Islam, Vol. 8, No. 1, Juni 2016: 89-116

Nafi', M. D., dkk. (2007). Praksis Pembelajaran Pesantren. Yogyakarta: Institute for Training and Development Amherst MA.

Nasution, H. (1985). Islam Ditinjau dari Beberapa Aspeknya. Jakarta: UI Press.

Sudarsono. (2004). Kenakalan Remaja. Jakarta: Rineka Cipta.

Sugiyono. (2011). Metode Penelitian Kuantitatif dan Kualitatif dan $R \& D$. Bandung: Alfabeta.

Suprayogo, I. \& Tabroni. (2001). Metodologi Penelitian Sosial Agama. Bandung: PT Remaja Rosdakarya.

Sriyanti, L., dkk. (2011). Teori-Teori Belajar. Salatiga: STAIN Salatiga.

Tim. (2009). Pedoman Penulisan Skripsi dan Tugas Akhir. Salatiga: STAIN Salatiga.

Yasid, A. (2004). Islam Akomodatif. Yogyakarta: LKiS 